ORIGINAL ARTICLE

\title{
Discriminant analysis: peculiarities of impact of sports specialization on 3rd-year female students' functional and motor fitness
} \author{
Sviatoslava Pashkevich ${ }^{4 \mathrm{ACD}}$ \\ ${ }^{1}$ Donbas State Engineering Academy, Ukraine \\ ${ }^{2}$ Gdansk University of Physical Education and Sport, Poland \\ ${ }^{3}$ H. S. Skovoroda Kharkiv National Pedagogical University, Ukraine \\ ${ }^{4}$ Kharkiv State Academy of Physical Culture, Ukraine
}

Serhii Chernenko ${ }^{1 \mathrm{ABCD}}$, Wladyslaw Jagiello ${ }^{2 \mathrm{ACD}}$, Olha Ivashchenko ${ }^{3 \mathrm{ACD}}$, Oleg Khudolii ${ }^{3 \mathrm{ACD}}$,

Authors' Contribution: A - Study design; B - Data collection; C - Statistical analysis; D - Manuscript Preparation; E - Funds Collection.

\begin{abstract}
Background The objective of the study was to determine the peculiarities of impact of sports specialization on 3rd-year and Study Aim female students' functional and motor fitness.

Material and The study involved 3rd-year female students of the Donbas State Engineering Academy in Kramatorsk, who Methods practiced badminton $(n=43)$, aerobics $(n=43)$, and callanetics $(n=43)$. To solve the tasks set, the following research methods were used: analysis of scientific literature, pedagogical observation, pedagogical testing; index method and medical-biological methods. Pedagogical methods were used to study the peculiarities of students' functional state of the body and motor abilities; for data processing discriminant analysis was used. Sectional classes were held in groups according to the schedule - twice a week.

Results The study revealed the peculiarities of impact of attending badminton, aerobics, and callanetics sports sections on the level of 3rd-year female students' functional and motor fitness. The female students who play badminton show better results in the 100-meter dash and the Standing long jump. In the exercise "Push-ups", better results are shown by the female students who do aerobics.

Conclusions The results of classification of students by the level of motor and functional fitness and the analysis of multidimensional averages (centroids) point to the peculiarities of dynamics of female students' state depending on sports specialization. The results of the following tests are most important for differentiated assessment of the state of motor and functional fitness at the first level: Romberg test $(r=0.662), 100$-meter dash $(r=0.491)$, Push-ups $(r=0.491)$. At the second level - Stange test $(r=0.417)$, Standing long jump $(r$ $=0.412$ ).

Keywords: $\quad$ students, badminton, aerobics, callanetics, discriminant analysis.
\end{abstract}

\section{Introduction}

Recently, there has been a noticeable deterioration in the state of health and a decline in motor fitness of students throughout the country, which causes concern among physical education specialists [1-3].

Decreased physical activity and motivation to exercise among adults, as well as children and young people is a global phenomenon [4-6]. Sigmundová et al. [4] point out that $69 \%$ of female students and $74 \%$ of male students of Czech universities meet the 10,000 steps daily criterion on four or more days per week; Cachón-Zagalaz et al. [5] focus on using the method for identifying professionally important qualities as components of a student's competency levels and their physical activity levels; Doroshenko et al. [6] indicate that taking into account female students' motor age during recreational aerobics classes ensures optimal motor activity and increases the level of physical fitness.

A number of studies are aimed at studying the dynamics of motor fitness [7-9], the influence of predominant orientation means on students' motor and functional fitness [10-12], methods of fundamental movement

\footnotetext{
(c) Serhii Chernenko, Wladyslaw Jagiello, Olha Ivashchenko,

Oleg Khudolii, Sviatoslava Pashkevich, 2021

doi:10.15561/20755279.2021.0606
}

screening [13-15].

Much less research focuses on studying the functional peculiarities of the cardiovascular and respiratory systems, motor fitness of student youth under the influence of sports $[1,16,17]$.

Multidimensional methods of mathematical statistics, such as factor and discriminant analysis are effective methods of studying the peculiarities of functional and motor fitness $[18,19,20]$. Discriminant analysis is used to assess both the results of sports training [21-23] and recreational classes [24-26].

The objective of the study was to determine the peculiarities of impact of sports specialization on 3rd-year female students' functional and motor fitness.

\section{Materials and methods}

Study participants

The study involved 3rd-year female students of the Donbas State Engineering Academy in Kramatorsk, who practiced badminton $(n=43)$, aerobics $(n=43)$, and callanetics $(n=43)$. The study started after the approval of the Research Ethics Committee of the Academy.

Study organization

To solve the tasks set, the following research methods 
were used: analysis of scientific literature, pedagogical observation, pedagogical testing; index method and medical-biological methods. Pedagogical methods were used to study the peculiarities of students' functional state of the body and motor abilities; for data processing discriminant analysis was used. Sectional classes were held in groups according to the schedule - twice a week.

Testing procedure

The testing program included well-known tests proposed by Serhiyenko [27]: Standing long jump (cm), 100-meter dash (s), Push-ups (times), Romberg test.

The Ruffier index, the Stange test, the Genchi test were used to assess the functional state [28, 29].

Ruffier-Dickson index. The test was used to assess cardiovascular performance during exercise.

Equipment: Stopwatch, tonometer, a device for measuring blood pressure.

Testing procedure. After 5 minutes of sitting calmly, the number of pulses was counted for 15 seconds (P1). Then 30 squats were performed for 45 seconds, using a metronome. Immediately after squatting, the pulse was measured for the first 15 seconds (P2) and the last 15 seconds (P3) of the first minute after the end of exercise.

Testing evaluation. The results are evaluated by an index determined by the formula: Ruffier index $=(\mathrm{P} 3+$ P2 - P1 - 70)/10. Ruffier index: 0-5 - good cardiovascular performance; 5.1-10 - average result; 10.1-15 satisfactory (moderate heart insufficiency); 15.1-20 - bad (significant heart insufficiency).

Stange test. The test was used to assess the functional state of the respiratory system.

Equipment: Stopwatch.

Testing procedure. In a sitting position, the subject inhales deeply and exhales, then inhales again (approximately $80 \%$ of the maximum), closes the mouth and simultaneously pinches the nose with fingers, holds breath (timing begins when inhale finishes and stops when exhale starts).

Testing evaluation. Breathhold: up to $35 \mathrm{~s}$ - fatigue; for 40-55 s - healthy untrained; for 60-90 s - healthy trained.

Genci test. The test was used to assess the functional state of the respiratory system.

Equipment: Stopwatch.

Testing procedure. The Genci test involves breathholding after exhalation. It was conducted not earlier than 5-7 minutes after the Stange test.

Testing evaluation. Breathhold: up to $20 \mathrm{~s}$ - fatigue; for 25-30 s - healthy untrained; for 40-60 s - healthy trained.

Romberg test. The test is used to assess static balance.

Equipment: Stopwatch.

Testing procedure. The participant stands with the feet on one line, one in front of the other, eyes closed, arms forward. Timing begins at the moment when a steady position is assumed, the test stops when the steady position is lost.

Result. The time of holding a steady position in seconds is recorded.

Testing evaluation. Normally, balance should not be lost for 30 seconds.
Statistical analysis

The study results were processed by the method of mathematical statistics. The following parameters were calculated: arithmetic mean (x), error in calculating the arithmetic mean (s); significance of difference between means ( $t)$. The significance of difference between statistical indicators $(t)$ was evaluated using the Student's t-test. Discriminant analysis created a prognostic model for group membership. This model builds a discriminant function (or, for more than two groups, a set of discriminant functions) in the form of a linear combination of predictor variables, which provides the best discrimination between the groups. These functions are developed from a sample of cases for which their group membership is known. These functions can be further used for new cases with known values of predictor variables and unknown group membership. For each variable, the following values are calculated: means, standard deviations, one-way ANOVA (Box's M test, within-group correlation matrix, within-group covariance matrix, covariance matrices for separate groups, total covariance matrix). For each canonical discriminant function: eigenvalue, percentage of variance, canonical correlation, Wilks' Lambda, Chisquare. For each step: prior probabilities, Fisher's function coefficients, unstandardized function coefficients, Wilks' Lambda for each canonical function.

\section{Results}

Tables 1-2 show the results of analysis of the motor and functional fitness of 3rd-year female students attending badminton, aerobics, and callanetics sports sections. It was found that by the level of fitness the female students of the three groups differ statistically significantly both at the beginning of attending the section and after a year of training. According to the Ruffier index, the female students have a satisfactory level of heart performance. According to the indicators of the Stange test, they are assessed as healthy untrained. According to the Genchi test - as healthy trained. According to the Romberg test indicators, the female students show below normal results.

The female students who play badminton show better results in the 100-meter dash and the Standing long jump. In the exercise "Push-ups", better results are shown by the female students who do aerobics.

Discriminant analysis was conducted to identify the peculiarities of the female students' motor and functional fitness. The first canonical function explains $53.5 \%$ of the variation of results, the second function $-34.1 \%$, which indicates their high informativeness $\left(r_{1}=0.619\right.$; $r_{2}=0.532$ ) (see Table 3). The materials of analysis of the canonical functions show a statistical significance of the first, second, and third canonical functions $\left(\lambda_{1}=\right.$ $0.384 ; \mathrm{p}_{1}=0.001 ; \lambda_{2}=0.623 ; \mathrm{p}_{2}=0.001 ; \lambda_{3}=0.870 ; \mathrm{p}_{2}=$ 0.002 ). The first, second, and third functions have a high discriminative ability and value in interpretation of the general population (Table 4).

Tables 5 and 6 show the standardized and structure canonical discriminant function coefficients. The results of the following tests are most important for differentiated 
Table 1. Group Statistics

\begin{tabular}{|c|c|c|c|c|c|c|c|c|c|c|c|c|}
\hline \multirow{3}{*}{ Indicators } & \multicolumn{4}{|c|}{ Badminton } & \multicolumn{4}{|c|}{ Aerobics } & \multicolumn{4}{|c|}{ Callanetics } \\
\hline & \multicolumn{2}{|c|}{ pre-test } & \multicolumn{2}{|c|}{ post-test } & \multicolumn{2}{|c|}{ pre-test } & \multicolumn{2}{|c|}{ post-test } & \multicolumn{2}{|c|}{ pre-test } & \multicolumn{2}{|c|}{ post-test } \\
\hline & $M$ & SD & $M$ & SD & $M$ & SD & $M$ & SD & M & SD & $M$ & SD \\
\hline Ruffier index & 14.7 & 5.1 & 14.3 & 4.2 & 14.3 & 4.2 & 12.0 & 3.4 & 12.9 & 3.1 & 12.6 & 2.9 \\
\hline Stange test, s & 55.1 & 17.2 & 64.0 & 31.8 & 44.8 & 9.8 & 49.8 & 11.7 & 38.6 & 12.1 & 44.1 & 12.9 \\
\hline Genchi test, s & 43.5 & 10.7 & 41.4 & 15.0 & 31.0 & 7.6 & 35.3 & 8.1 & 32.5 & 10.1 & 40.1 & 12.4 \\
\hline Romberg test, s & 7.0 & 4.2 & 5.7 & 2.7 & 10.9 & 7.4 & 13.3 & 6.1 & 4.7 & 3.4 & 6.6 & 5.2 \\
\hline 100-meter dash, s & 16.2 & 1.7 & 15.8 & 1.7 & 17.7 & 1.2 & 17.2 & 1.0 & 17.6 & 1.2 & 17.3 & 1.1 \\
\hline $\begin{array}{l}\text { Standing long } \\
\text { jump, cm }\end{array}$ & 198.3 & 31.1 & 208.8 & 32.5 & 179.1 & 14.2 & 184.8 & 14.0 & 179.3 & 15.6 & 180.4 & 30.3 \\
\hline Push-ups, times & 15.7 & 6.8 & 16.9 & 7.3 & 18.8 & 5.3 & 22.3 & 4.1 & 16.6 & 6.7 & 17.1 & 6.3 \\
\hline
\end{tabular}

Table 2. Tests of Equality of Group Means

\begin{tabular}{llllll}
\hline Indicators & Wilks' Lambda & F & df1 & df2 & Sig. \\
\hline Ruffier index & .937 & 3.387 & 5 & 252 & .006 \\
Stange test, s & .816 & 11.381 & 5 & 252 & .000 \\
Genchi test, s & .844 & 9.290 & 5 & 252 & .000 \\
Romberg test, s & .734 & 18.218 & 5 & 252 & .000 \\
100-meter dash, s & .784 & 13.925 & 5 & 252 & .000 \\
Standing long jump (cm) & .822 & 10.919 & 5 & 252 & .000 \\
Push-ups, times & .890 & 6.240 & 5 & 252 & .000 \\
\hline
\end{tabular}

Table 3. Eigenvalues

\begin{tabular}{lllll}
\hline Function & Eigenvalue & \% of Variance & Cumulative \% & Canonical Correlation \\
\hline 1 & $.621^{\mathrm{a}}$ & 53.5 & 53.5 & .619 \\
2 & $.396^{\mathrm{a}}$ & 34.1 & 87.6 & .532 \\
3 & $.087^{\mathrm{a}}$ & 7.5 & 95.1 & .283 \\
4 & $.054^{\mathrm{a}}$ & 4.6 & 99.7 & .226 \\
5 & $.003^{\mathrm{a}}$ & .3 & 100.0 & .058 \\
\hline
\end{tabular}

Table 4. Wilks' Lambda

\begin{tabular}{lllll}
\hline Test of Function(s) & Wilks' Lambda & Chi-square & df & Sig. \\
\hline 1 through 5 & .384 & 239.511 & 35 & .000 \\
2 through 5 & .623 & 118.447 & 24 & .000 \\
3 through 5 & .870 & 34.967 & 15 & .002 \\
4 through 5 & .946 & 14.016 & 8 & .081 \\
5 & .997 & .845 & 3 & .839 \\
\hline
\end{tabular}

assessment of the state of motor and functional fitness at the first level: 100 -meter dash $(r=0.586)$, Standing long jump $(\mathrm{r}=-0.493)$. At the second level - Romberg test $(\mathrm{r}=$ $0.614)$, at the third level - Genci test $(r=-0.803)$.

The analysis of multidimensional averages (centroids) shows different levels of motor and functional fitness of the female students according to pre-test and post-test results. There are peculiarities of dynamics of the female students' state depending on sports specialization (Table 7, Fig. 1).

Discriminant analysis of the three groups. Post-test

To clarify the impact of specialization on the 3rd-year female students' functional and motor fitness, the study conducted a discriminant analysis of post-test results in groups practicing badminton, aerobics, and callanetics. The first canonical function explains $66.4 \%$ of the variation of results, the second function $-33.6 \%$, which indicates their high informativeness $\left(r_{1}=0.689 ; r_{2}=0.560\right)$ (Table 8 ). The materials of analysis of the canonical functions show a statistical significance of the first and second canonical functions $\left(\lambda_{1}=0.360 ; \mathrm{p}_{1}=0.001 ; \lambda_{2}=0.686\right.$; $\left.\mathrm{p}_{2}=0.001\right)$. The first and second functions have a high discriminative ability and value in interpretation of the general population (Table 9).

Tables 10 and 11 show the standardized and structure canonical discriminant function coefficients. The results of the following tests are most important for differentiated assessment of the state of motor and functional fitness at 
Table 5. Standardized Canonical Discriminant Function Coefficients

\begin{tabular}{llllll}
\hline \multirow{2}{*}{ Indicators } & Function & & & & \\
\cline { 2 - 6 } & $\mathbf{1}$ & $\mathbf{2}$ & $\mathbf{3}$ & $\mathbf{4}$ & $\mathbf{5}$ \\
\hline Ruffier index & -.345 & .401 & .311 & .696 & .000 \\
Stange test & -.236 & .537 & .321 & -.200 & .835 \\
Genchi test & -.372 & -.254 & -.889 & .276 & .108 \\
Romberg test & .526 & .668 & -.219 & .440 & -.171 \\
100-meter dash & .435 & -.062 & .308 & .089 & .534 \\
Standing long jump & -.073 & .478 & .438 & -.169 & -.377 \\
Push-ups & .236 & .257 & -.126 & -.570 & -.033 \\
\hline
\end{tabular}

Table 6. Structure Matrix

\begin{tabular}{llllll}
\hline \multirow{2}{*}{ Indicators } & Function & & & & \\
\cline { 2 - 6 } & $\mathbf{1}$ & $\mathbf{2}$ & $\mathbf{3}$ & $\mathbf{4}$ & $\mathbf{5}$ \\
\hline 100-meter dash & $.586^{*}$ & -.373 & .183 & .266 & .520 \\
Standing long jump & $-.493^{*}$ & .386 & .053 & -.329 & -.443 \\
Romberg test & .558 & $.614^{*}$ & -.410 & .286 & -.080 \\
Genchi test & -.446 & .100 & $-.803^{*}$ & .054 & .204 \\
Ruffier index & -.205 & .109 & .378 & $.665^{*}$ & .007 \\
Push-ups & .347 & .295 & -.202 & $-.456^{*}$ & .040 \\
Stange test & -.412 & .537 & -.081 & -.285 & $.624^{*}$ \\
\hline
\end{tabular}

Table 7. Functions at Group Centroids

\begin{tabular}{llllll}
\hline $\mathbf{1}, \mathbf{3}, \mathbf{5}$ - pre-test; $\mathbf{2 ,} \mathbf{4}, \mathbf{6}-$ post-test & Function & \multicolumn{3}{l}{} \\
\cline { 2 - 6 } & $\mathbf{1}$ & $\mathbf{2}$ & $\mathbf{3}$ & $\mathbf{4}$ & $\mathbf{5}$ \\
\hline 1.00 & -.863 & .151 & -.205 & .302 & -.070 \\
2.00 & -1.113 & .545 & .220 & -.239 & .042 \\
3.00 & .788 & .280 & .346 & .308 & .043 \\
4.00 & 1.000 & .698 & -.263 & -.217 & -.036 \\
5.00 & .193 & -.963 & .287 & -.161 & -.060 \\
6.00 & -.005 & -.710 & -.386 & .007 & .080 \\
\hline
\end{tabular}

Table 8. Eigenvalues

\begin{tabular}{lllll}
\hline Function & Eigenvalue & \% of Variance & Cumulative \% & Canonical Correlation \\
\hline 1 & .905 & 66.4 & 66.4 & .689 \\
2 & .458 & 33.6 & 100.0 & .560 \\
\hline
\end{tabular}

Table 9. Wilks' Lambda

\begin{tabular}{lllll}
\hline Test of Function(s) & Wilks' Lambda & Chi-square & df & Sig. \\
\hline 1 through 2 & .360 & 125.654 & 14 & .000 \\
2 & .686 & 46.381 & 6 & .000 \\
\hline
\end{tabular}

the first level: Romberg test $(\mathrm{r}=0.662), 100$-meter dash $(\mathrm{r}=0.491)$, Push-ups $(\mathrm{r}=0.491)$. At the second level Stange test $(r=0.417)$, Standing long jump $(r=0.412)$.

The analysis of multidimensional averages (centroids) shows different levels of motor and functional fitness of the female students according to post-test results. There are peculiarities of dynamics of the female students' state depending on sports specialization (Table 12, Fig. 2). The results of classification of the female students by the level of motor and functional fitness show that $71.3 \%$ of the students were classified correctly (Table 13).

\section{Discussion}

The study assumed that on the basis of discriminant analysis it is possible to determine the peculiarities of the functional and motor fitness of female students attending badminton, aerobics, and callanetics sports sections. The testing of discriminant functions revealed that they have a high discriminative ability and value in interpretation of the general population.

The data presented add up to the results of the study by Ivashchenko [18, 30], Chernenko et al. [19] on the effectiveness of discriminant analysis in assessing 


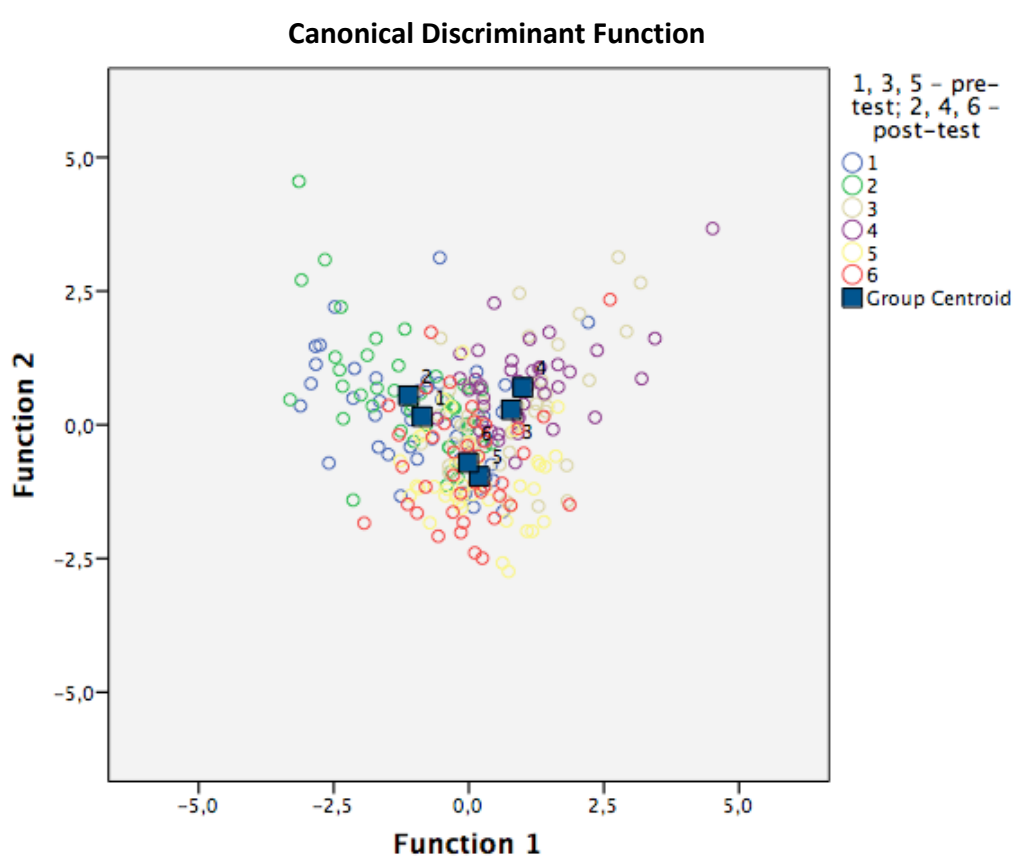

Fig. 1. Indicators of female students' fitness depending on sports specialization: 1,2 - badminton; 3, 4-aerobics; 5, 6 - callanetics

Table 10. Standardized Canonical Discriminant Function Coefficients

\begin{tabular}{lll}
\hline \multirow{2}{*}{ Indicators } & Function & \\
\cline { 2 - 3 } & $\mathbf{1}$ & $\mathbf{2}$ \\
\hline Ruffier index & -.502 & .462 \\
Stange test & -.276 & .507 \\
Genchi test & -.164 & -.481 \\
Romberg test & .577 & .542 \\
100-meter dash & .476 & -.119 \\
Standing long jump & -.044 & .675 \\
Push-ups & .286 & .388 \\
\hline
\end{tabular}

Table 11. Structure Matrix

\begin{tabular}{lll}
\hline Indicators & Function & $\mathbf{2}$ \\
\cline { 2 - 3 } & $\mathbf{1}$ & .453 \\
Romberg test & $.662^{*}$ & -.396 \\
100-meter dash & $.491^{*}$ & .309 \\
Push-ups & $.377^{*}$ & .094 \\
Ruffier index & $-.281^{*}$ & -.114 \\
Genchi test & $-.214^{*}$ & $.417^{*}$ \\
Stange test & -.302 & $.412^{*}$ \\
Standing long jump & -.396 & \\
\hline
\end{tabular}

Table 12. Functions at Group Centroids

\begin{tabular}{lll}
\hline $\mathbf{1}$ - badminton; 2 - aerobics; 3 - callanetics & Function & $\mathbf{2}$ \\
\cline { 2 - 3 } & $\mathbf{1}$ & .448 \\
1.00 & -1.171 & .498 \\
2.00 & 1.131 & -.945 \\
3.00 & .040 & \\
\hline
\end{tabular}




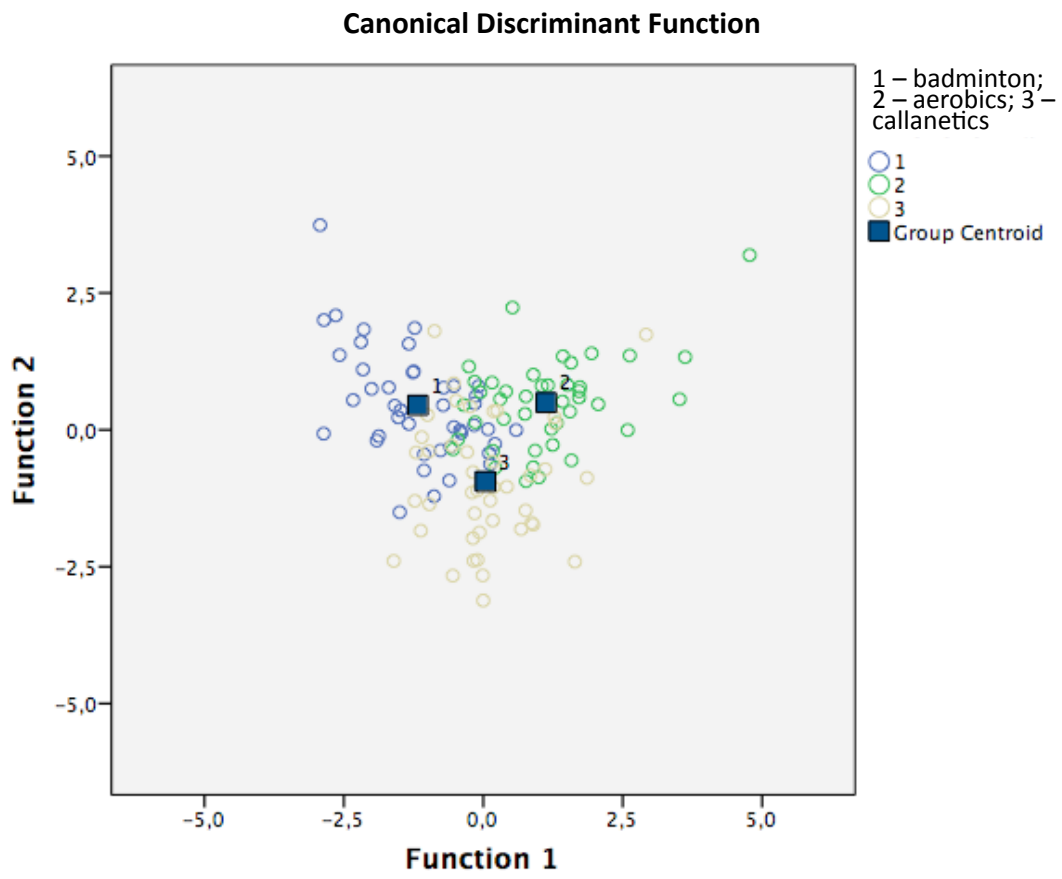

Fig. 2. Indicators of female students' fitness depending on sports specialization: 1 - badminton; 2 - aerobics; 3 callanetics

Table 13. Classification Results

\begin{tabular}{|c|c|c|c|c|c|c|}
\hline & & \multirow{2}{*}{$\begin{array}{l}\text { 1-badminton; } 2 \text { - aerobics; } \\
3 \text { - callanetics }\end{array}$} & \multicolumn{3}{|c|}{ Predicted Group Membership } & \multirow{2}{*}{ Total } \\
\hline & & & 1.00 & 2.00 & 3.00 & \\
\hline \multirow{6}{*}{ Original } & \multirow{3}{*}{ Count } & 1.00 & 32 & 1 & 10 & 43 \\
\hline & & 2.00 & 5 & 31 & 7 & 43 \\
\hline & & 3.00 & 8 & 6 & 29 & 43 \\
\hline & \multirow{3}{*}{$\%$} & 1.00 & 74.4 & 2.3 & 23.3 & 100.0 \\
\hline & & 2.00 & 11.6 & 72.1 & 16.3 & 100.0 \\
\hline & & 3.00 & 18.6 & 14.0 & 67.4 & 100.0 \\
\hline
\end{tabular}

a.71.3\% of original grouped cases correctly classified

students' functional and motor fitness.

The findings show that the 3rd-year girls most significantly differ in the results of coordination fitness testing. According to the Romberg test, the female students show below normal results. The data confirm that the third year is a problematic period in physical education of students [19]. The findings complement the information on the need for additional introduction of more intensive forms of classes into the system of physical education of students $[2,11,31]$, on the importance of motor activity in the educational process of students [32-34].

An important conclusion is that the results of the following tests are most significant for differentiated assessment of the state of motor and functional fitness at the first level: Romberg test $(r=0.662), 100$-meter dash $(\mathrm{r}=0.491)$, Push-ups $(\mathrm{p}=0.491)$. At the second level Stange test $(r=0.417)$, Standing long jump $(r=0.412)$. The results complement the data on pedagogical control in physical education of students $[6,35]$.

Thus, to assess functional and motor fitness, the first discriminant function and the function value in group centroids can be used, as the results of classification of the female students by the level of motor and functional fitness show that $71.3 \%$ of the students were classified correctly.

\section{Conclusions}

The results of classification of students by the level of motor and functional fitness and the analysis of multidimensional averages (centroids) point to the peculiarities of dynamics of female students' state depending on sports specialization. Female students who play badminton show better results in the 100-meter dash and the Standing long jump. In the exercise "Pushups", better results are shown by female students who do aerobics.

The results of the following tests are most important for differentiated assessment of the state of motor and functional fitness at the first level: Romberg test $(\mathrm{r}=$ 0.662), 100-meter dash $(r=0.491)$, Push-ups $(r=0.491)$. At the second level - Stange test $(r=0.417)$, Standing long jump $(r=0.412)$. 


\section{References}

1. Chernenko S, Honcharenko O, Marchenko S. Informative Indicators of Functional and Motor Fitness of Students of Higher Education Institutions. Teoriâ ta Metodika Fìzičnogo Vihovannâ, 2019; 19(3): 107-115. https://doi.org/10.17309/tmfv.2019.3.01

2. Solohubova S, Lakhno O, Shyyan V, Shyyan O. The Assessment of Physical Fitness and Morphofunctional State of Female First-Year Students in Non-Linguistic Higher Education Institutions. Teorîa ta Metodika Fizičnogo Vihovannâ, 2020; 20(3); 157-164. https://doi.org/10.17309/tmfv.2020.3.05

3. Bielikova N, Tsos A, Indyka S, Contiero D, Pantik V, Tomaschuk O, Dedeliuk N, Podubinska S. The motor activity status and students' self- assessment of health during a covid-19 pandemic. Sport Mont. 2021; 19: 95-99. https://doi.org/10.26773/smj.210901

4. Sigmundová D, Chmelík F, Sigmund E, Feltlová D, Frömel K. Physical activity in the lifestyle of Czech university students: Meeting health recommendations. Eur J Sport Sci. 2013; 13(6): 744-50. https://doi.org/10.1080/17461391.2013.776638

5. Cachón-Zagalaz J, Sánchez-Zafra M, Lara-Sánchez A, Zagalaz-Sánchez ML, Shmatkov D. Study on the relationship between physical activity and the development of professional competence: Findings from a study in Ukraine. Journal of Human Sport and Exercise, 2020; 15(3): 591-607. https://doi.org/10.14198/jhse.2020.153.10

6. Doroshenko E, Hurieieva A, Symonik A, Chernenko O, Chernenko A, Serdyuk D, Svatiev A, Tsarenko K. Differentiation of Physical Loads in Female Students of Different Motor Ages. Teoriâ ta Metodika Fìzičnogo Vihovannâ, 2021; 21(2): 158-166. https://doi.org/10.17309/tmfv.2021.2.09

7. Kramer PA. The effect on energy expenditure of walking on gradients or carrying burdens. American Journal of Human Biology, 2010; 22(4): 497-507. https://doi.org/10.1002/ajhb.21027

8. Almeida L, Fernandes HM. Relationship between physical education, school satisfaction, psychological well-being and academic achievement in vocational students. Journal of Human Sport and Exercise, 2019; 14(proc4): S1427-S1429.

9. Pashkevich S, Kriventsova I, Galicheva K. Using Movement Test to Evaluate Effectiveness of Health and Fitness Activities of Students in Higher Education Institutions. Teoriâ ta Metodika Fizičnogo Vihovannâ, 2018; 18(1): 12-22. https://doi.org/10.17309/tmfv.2018.1.02

10.Aguilera DA, Rivera-Aguilera VS, Cordovés-Peinado R. Strategy proposal for the redesign of the Subject Program Athletics I of the Physical Education career curriculum approach by competence according to the educational model of the university. Journal of Human Sport and Exercise, 2020; 15(Proc4); 1394-1406. https://doi.org/10.14198/jhse.2020.15.Proc4.36

11.Amin HM, Karim AA, Jassim RAW. Prediction of some types of handball throws according to the attention expressions of physical education and sports Sciences female students. Journal of Human Sport and Exercise, 2019; 14(Proc5): S1842-S1852. https://doi.org/10.14198/jhse.2019.14.Proc5.03

12.Aparicio-Sarmiento A, Gómez-Carmona CD, MartínezRomero MT, Gamonales JM, Sainz De Baranda P. The effect of a specific core training program in physical education on perceived exertion and technique. Journal of Sport and Health Research, 2021; 13(2): 195-210.
13.Newton F, McCall A, Ryan D, Blackburne C, aus der Fünten K, Meyer T, Lewin C, McCunn R. Functional Movement Screen (FMS ${ }^{\mathrm{TM}}$ ) score does not predict injury in English Premier League youth academy football players. Science and Medicine in Football, 2017; 1(2): 102-106. https://doi.org/10.1080/24733938.2017.1283436

14.Liao T, Zheng W, Meng Y. Application of Functional Movement Screen to the Evaluation of Youth's Physical Health. In: Salmon P., Macquet AC. (eds) Advances in Human Factors in Sports and Outdoor Recreation. Advances in Intelligent Systems and Computing, 2017; 496. https://doi.org/10.1007/978-3-319-41953-4_17

15.Tsigilis N, Douda H, Tokmakidis SP. Test-retest reliability of the Eurofit test battery administered to university students. Perceptual and Motor Skills, 2002; 95(3): 1295-1300. https://doi.org/10.2466/PMS.95.8.1295-1300

16.Cosma G, Chiracu A, Stepan A, Gatzel R, Iancu A, Cosma A. Sportsmanship and basic psychological needs in sports students. Balt J Health Phys Activ. 2021; 13: 53-65. https://doi.org/10.29359/BJHPA.13.Spec.Iss1.05

17.Kovács K, Moravecz M, Nagy Z, Rábai D, Szabó D. The institutional effect on leisure time and competitive sports at higher education colleges and universities in the Carpathian Basin. Balt J Health Phys Activ. 2020; 12: 46-59. https://doi.org/10.29359/BJHPA.12.Spec.Iss1.06

18.Ivashchenko O. Methodic of pedagogic control of 16-17 years' age girls' motor fitness. Pedagogics, Psychology, Medical-Biological Problems of Physical Training and Sports, 2016; 20(5): 26-32. https://doi.org/10.15561/18189172.2016.0504

19.Chernenko S, Iermakov S, Oliinyk O, Dolynnyi Y. Pattern Recognition:Description ofFunctionalandMotorPreparedness of Students of Higher Educational Institutions. Teoriâ ta Metodika Fìzičnogo Vihovannâ, 2018; 18(4): 200-206. https://doi.org/10.17309/tmfv.2018.4.06

20.Sgro' F, Quinto A, Pignato S, Lipoma M. Comparison of product and process oriented model accuracy for assessing countermovement vertical jump motor proficiency in pre-adolescents. Journal of Physical Education and Sport, 2016; 16(3): 921-926. https://doi.org/10.7752/jpes.2016.03145

21.LindnerKJ, Caine DJ., Johns DP. Withdrawal predictors among physical and performance characteristics of female competitive gymnasts. Journal of Sports Sciences, 1991; 9(3): 259-272. https://doi.org/10.1080/02640419108729888

22.Jukić, I., Milanović, D., \& Vuleta, D. (1999). Analysis of changes in indicators of functional and motor readiness of female basketball players within one-year training cycles. Collegium Antropologicum, 1999; 23(2): 691-706.

23.Pion J, Hohmann A, Liu T, Lenoir M, Segers V. Predictive models reduce talent development costs in female gymnastics. Journal of Sports Sciences, 2017; 35(8): 806-811. https://doi.org/10.1080/02640414.2016.1192669

24.Laughlin NT, Busk PL. Relationships between selected muscle endurance tasks and gender. Journal of Strength and Conditioning Research, 2007; 21(2): 400-404. https://doi.org/10.1519/R-16204.1

25.Fridolfsson J, Arvidsson D, Andersen LB, Thorsson O, Wollmer P, Rosengren B, Karlsson MK, Dencker M. Physical activity spectrum discriminant analysis - Amethod to compare detailed patterns between groups. Scandinavian Journal of Medicine and Science in Sports, 2021; 31(12): 2333-2342. https://doi.org/10.1111/sms.14052

26.Kumar AM. Regular discovery and sorting of workout in the health scenario. Indian Journal of Public Health 
Research and Development, 2017; 8(3): 91-95. https://doi.org/10.5958/0976-5506.2017.00247.9

27.Serhiienko LP. Comprehensive testing of human motor abilities. Mykolaiv: UDMTU; 2001. (In Ukrainian).

28.Romanenko VA. Human motor ability. Donetsk: New World; 1999. (In Russian).

29.Krutcevich TIu. Methods of researching the individual health of children and adolescents in the process of physical education. Kiev: Olympic literature; 1999. (In Russian).

30.Ivashchenko O. Research Program: Modeling of Motor Abilities Development and Teaching of Schoolchildren. Teoriâ ta Metodika Fìzičnogo Vihovannâ, 2020; 20(1): 32-41. https://doi.org/10.17309/tmfv.2020.1.05

31.Choi SM, Sum KWR, Wallhead TL, Leung FLE, Ha SCA, Sit HPC. Operationalizing physical literacy through sport education in a university physical education program. Physical Education and Sport Pedagogy, 2021; 1-17. https://doi.org/10.1080/17408989.2021.1915266

32.Lynch S, Sargent J. Using the meaningful physical education features as a lens to view student experiences of democratic pedagogy in higher education. Physical Education and Sport Pedagogy, 2020; 25(6): 629-642. https://doi.org/10.1080/17408989.2020.1779684

33.Tohmea GM, Najam NR, Tohmea WM. The effect of pilates exercises on some physical components among first stage female students of the faculty of physical education and sports sciences Wasit University. Journal of Human Sport and Exercise, 2020; 15(Proc2): 146-153. https://doi.org/10.14198/jhse.2020.15.Proc2.04

34.Hovey K, Niland D, Foley JT. The impact of participation in an outdoor education program on physical education teacher education student self-efficacy to teach outdoor education. Journalof Teaching in PhysicalEducation, 2020;39(1);18-27. https://doi.org/10.1123/jtpe.2018-0288

35.Koryahin V, Turchyn Y, Blavt O, Dolnikova L. Information Systems of Support of Pedagogical Control in the Physical Education of Students. Teoriâ ta Metodika Fizičnogo Vihovannâ, 2020; 20(4): 205-211. https://doi.org/10.17309/tmfv.2020.4.02

\section{Information about the authors:}

Serhii Chernenko: http://orcid.org/0000-0001-9375-4220; chernenko.sergey65@ukr.net; Department of Physical Education, Donbas State Engineering Academy; Akademichna St, 72, Kramatorsk, 84313, Ukraine.

Wladyslaw Jagiello: https://orcid.org/0000-0001-7417-4749; wjagiello1@wp.pl; Gdansk University of Physical Education and Sport; Kasimir Gorskogo St, 1, 80-336 Gdansk, Poland.

Olha Ivashchenko: https://orcid.org/0000-0002-2708-5636; ivashchenko@hnpu.edu.ua; Department of Theory and Methodology of Physical Education, H. S. Skovoroda Kharkiv National Pedagogical University; Artema St, 29, Kharkiv, 61002, Ukraine.

Oleg Khudolii: (Corresponding Author); http://orcid.org/0000-0002-5605-9939; khudolii@hnpu.edu.ua; Department of Theory and Methodology of Physical Education, H. S. Skovoroda Kharkiv National Pedagogical University; Artema St, 29, Kharkiv, 61002, Ukraine.

Sviatoslava Pashkevich: https://orcid.org/0000-0002-4842-4350; sviatoslava.pashkevych@gmail.com; Department of Physical Therapy, Kharkiv State Academy of Physical Culture; Klochkivska St, 99, Kharkiv, 61022, Ukraine.

\section{Cite this article as:}

Chernenko S, Jagiello W, Ivashchenko O, Khudolii O, Pashkevich S. Discriminant analysis: peculiarities of impact of sports specialization on 3rd-year female students' functional and motor fitness. Physical Education of Students, 2021;25(6):374-381. https://doi.org/10.15561/20755279.2021.0606

This is an Open Access article distributed under the terms of the Creative Commons Attribution License, which permits unrestricted use, distribution, and reproduction in any medium, provided the original work is properly cited http://creativecommons.org/licenses/by/4.0/deed.en

Received: 02.11.2021

Accepted: 25.12.2021; Published: 30.12.2021 